\title{
TINJAUAN GAMBAR EKSPRESI OBJEK MANUSIA BERDASARKAN TEORI LOWENFELD MENGGUNAKAN KRAYON OLEH ANAK TK B METHODIST BERASTAGI
}

\author{
Crosby Sitepu $^{1 *}$, Azmi $^{2 *}$, Anam Ibrahim ${ }^{3 *}$ Adek Cerah Kurnia Azis ${ }^{4 *}$ \\ Program Studi Pendidikan Seni Rupa Jurusan Seni Rupa Fakultas Bahasa dan Seni \\ Universitas Negeri Medan \\ Jl. Willem Iskandar Pasar V Medan Estate, Kec, Percut Sei Tuan, Kab. Deli Serdang, Kode Pos 20371 \\ Sumatera Utara. Indonesia \\ Email: crosbya0710@gmail.com
}

\begin{abstract}
Abstrak
Penelitian ini bertujuan untuk mendeskripsikan kemampuan gambar ekspresi objek manusia dari indikator bentuk, warna, dan kerapian melalui menggambar menggunakan krayon yang dilaksanakan di TK B Methodist Berastagi berdasarkan teori Lowenfeld. Penelitian ini merupakan penelitian deskriptif kualitatif. Subjek penelitian ini adalah 3 peserta didik di TK B 3 Methodist Berastagi Kecamatan Berastagi Kabupaten Karo Provinsi Sumatera Utara. Objek penelitian ini yaitu kemampuan menggambar ekspresi. Metode pengumpulan data yang digunakan adalah observasi dan dokumentasi. Analisis data menggunakan teknik analisis deskriptif kualitatif. Hasil penelitian ini menunjukkan bahwa kemampuan menggambar ekspresi objek manusia dengan krayon berdasarkan teori Lowenfeld pada peserta didik di TK B 3 Methodist Berastagi adalah baik. Karakteristik gambar ekspresi karya peserta didik TK B 3 Methodist Berastagi telah memiliki konsep cerita sesuai dengan imajinasi dan juga sesuai dengan kedaan lingkungan sekitar mereka, seperti didalam ruang lingkup keluarga dan kelas mereka.
\end{abstract}

Kata Kunci: gambar, ekspresi, anak, TK, lowenfeld.

\begin{abstract}
This study was designed to describe the ability of images that depict human objects from indicators of shape, color, and neatness through drawing using crayons conducted at Kindergarten B Methodist Berastagi through Lowenfeld's theory.This research is a qualitative descriptive study. The subjects of this study were 26 students at the Kindergarten B 3 Methodist in Berastagi, Berastagi District, Karo Regency, North Sumatra Province. The object of this research is the ability to draw expressions. Data collection methods used are observation and documentation. Data analysis uses descriptive qualitative analysis techniques. The results of this study indicate that the ability to draw human object expressions with crayons based on Lowenfeld's theory of students in TK B 3 Methodist Berastagi is good. Characteristic images of expression by Kindergarten $B 3$ Methodist Berastagi students have a concept of the story in accordance with the imagination and also in accordance with the circumstances of their environment, such as in the scope of their families and classrooms.
\end{abstract}

Keywords: image, expressions, children, kindergarten, lowenfeld..

\section{PENDAHULUAN}

Usia dini merupakan usia awal yang paling penting dan mendasar sepanjang pertumbuhan dan perkembangan kehidupan manusia. Anak usia taman kanak-kanak (4-7 tahun) termasuk dalam masa keemasan (golden age). Masa keemasan adalah masa dimana seluruh aspek pertumbuhan anak berkembang secara cepat. Oleh karena itu, diperlukan bimbingan yang tepat untuk anak, baik dari orang tua, guru, atau lingkungan. Salah satu cara yang dapat dilakukan untuk meningkatkan aspek perkembangan anak pada masa keemasan ini adalah melalui lembaga Pendidikan Anak Usia Dini.

Aspek perkembangan anak meliputi aspek kognitif, bahasa, fisikmotorik, sosial-emosional, moral-agama, dan seni. Seiring dengan masa perkembangan anak, kegiatan kesenirupaan terhadap anak juga ikut berkembang, khususnya dalam pembuatan karya seni rupa yang berupa gambar. Secara umum dapat dikatakan bahwa karya seni rupa (gambar) bersifat ekspresif dan dinamis. 
Berdasarkan hasil observasi peneliti, dilihat dari hasil karya menggambar anak-anak TK B Methodist Berastagi, pada kenyataannya peserta didik belum terbiasa dengan pelajaran menggambar objek manusia, karena dalam kegiatan proses belajar seni pada anakanak TK B Methodist Berastagi guru masih kurang mengarahkan peserta didik dalam pembelajaran seni rupa terutama dalam bidang menggambar objek manusia, sehingga peserta didik sering sekali menggambar objek yang berbeda dengan objek gambar yang ditentukan oleh guru. Berkaitan dengan penggunaan media krayon pada objek gambar, peserta didik juga masih kurang menguasai penggunaan media tersebut. Dengan masalah tersebut anak-anak TK B Methodist Berastagi juga kurang percaya diri untuk mengekspresikan diri melalui kegiatan kesenirupaan terutama menggambar.

\section{KAJIAN TEORI}

\section{Pengertian Tinjauan}

Menurut Kamus Besar Bahasa Indonesia (2002:762) tinjauan berasal dari kata tinjau yang memiliki arti sebagai berikut melihat, mempelajari dengan cermat, memeriksa dan menduga. Tinjauan juga merupakan suatu pemeriksaan yang teliti, penyelidikan, kegiatan pengumpulan data, pengolahan data, dan analisis. Maka berdasarkan uaraian tersebut dapat disimpulkan bahwa tinjauan adalah proses pemeriksaan dalam penyelidikan terhadap peristiwa untuk menemukan masalah atau mengetahui keadaan sebenarnya dan yang perlu ditinjau pada kaya gambar ekspresi objek manusia anak TK Methodist Berastagi bagaimana bentuk, warna dan kerapian sesuai dengan teori Lowenfeld.

\section{Tinjauan Pendidikan Anak Usia Dini (TK)}

Menurut Muhammad (2009:17) "Sangat penting memberikan latihan menggambar dan mewarnai untuk anak usia dini, dalam konteks ini tujuannya adalah bagaimana supaya otak kanan anak anda terasah, sehinngga akan tumbuh dan berkembang dengan maksimal. Dengan menggambar atau mewarnai, imajinasi anak akan berkembang dengan semestinya dan dengan sejalannya proses kreativitas akan berkembang."

Menurut Lowenfeld (1958:02) “Art education, introduces in the early years of childhood may well mean the difference between a flexible, creative human being and one how, in spite of all learning, will not be able to apply it and will reamin an individual who lacks inner resources an has difficulty in his relationship on the invironment. Because perceiving, thingking, dan feelingare equally stressed in any creative process, art may well be the necessary balance for the child's intellect and his emotion yang artinyapendidikan seni, diperkenalkan pada awal tahun masa kanak-kanak,dapat membuat perbeaan antara manusia yang feksibel dan kreatif dan bagaimana caranya, terlepas dari semua pembelajaran, tidak akan dapat menerapkan dan akan memeriksa kembali seseorang yang tidak memiliki sumber daya diri dan kesulitan berhubungan lingkungannya. Karena pemahaman, pikiran dan perasaan bersamaan ditekankan dalam setiap proses kreatifnya, seni juga menjadi keseimbangan yang diperlukan untuk kecerdasan dan emosi anak tersebut".

\section{Periodisasi Perkembangan Seni Rupa Anak}

Gambar anak-anak dapat dikelompokkan berdasarkan periodisasi. Pengelompokkan periodisasi karya seni rupa anak (gambar) bertujuan untuk mengenali karakteristik perkembangan gambar anak berdasarkan usia. Periodisasi perkembangan gambar anak banyak dikemukakan oleh para ahli seni. Menurut Lowenfeld (1958:86-216) tahap perkembangan seni rupa anak ada lima, yaitu sebagai berikut :

\section{1). Tahap Coreng-Moreng (2-4 Tahun)}

Hal ini akan tidak terkendali pada awalnya, dan hasilnya adalah garis-garis, yang menunjukkan gerakan-gerakan yang tidak terarah ini. Tahap pertama dari mencoret-coret ini adalah coretan yang tidak beraturan, tebal atau kecil pada garis-garisnya.

\section{2). Tahap Prabagan (4-7 Tahun)}

Pada tahap ini anak telah dapat mengendalikan motoriknya dan dapat melihat hubungan antara yang dihasilkan dengan bentuk objek yang sebenarnya. Telah terjadi perubahan dari coret-coret kearah bentuk yang lebih esensial, sehingga bentuk yang dihasilkan oleh anak dapat ditafsirkan, lama-kelamaan akan terbentuk bagian-bagian lain yang lebih menunjang imajinasinya.

\section{3). Tahap Bagan (7-9 Tahun)}

Tahap ini merupakan tahap tentang bentuk dasar dari pengalaman kreatif, anak pada usia ini telah memiliki konsep cerita yang banyak. Pengamatan terhadap objek semakin teliti dan semakin tahu siapa dirinya dalam hubungan dengan lingkungannya. Pada usia ini pengaruh guru sangat besar. Anak telah memiliki pengalaman sosial, yaitu hal-hal yang sebenarnya sudah diketahui, disikapi karena desakan emosi subjektifnya. Tahapan ini mengacu pada cara yang sama untuk menggambar ruang dan benda. 
4). Tahap Permulaan Realisme (9-11 Tahun)

Bagi anak-anak tahapan ini mungkin periode penemuan yang paling dramatis dan sehat, terlihat jelas dalam karya kreatif anak. Anak usia 9-11 tahun dimasukkan dalam tahap permulaan realisme, pada tahap ini anak semakin cerdas dalam mengungkapkan imajinasinya. Objek semakin mendetail dan lebih proposional, seiring dengan meningkatnya intelektual anak.

\section{5). Tahap Realisme Semu (11-13 Tahun)}

Tahap realisme semu telah banyak dipengaruhi oleh intelegensi yang semakin matang. Untuk pola gambar sudah cukup matang dan pewarnaan juga sudah sesuai dengan objek yang sebenarnya, namun bentuk yang sudah realis masih kurang kuat. Artianya, gambar yang dihasilkan oleh anak telah realistis tetapi masih ada kekurangan sedikit dalam bentuk gambarnya.

\section{Pengertian Menggambar dan Gambar Ekspresi} Menurut Apryanto (2004:01) "Gambar merupakan bahasa yang universal dan telah berkembang sebelum ditemukannya bahasa tulis. Pada dasarnya, menggambar adalah keterampilan yang bisa dipelajari oleh setiap orang, terutama bagi yang punya minat untuk belajar". Menurut Rohman (2010:05) "Menggambar adalah sebuah proses kresi yang harus dilakukan secara intensif, rutin, dan terus-menerus". Selajutnya Susanto (2018:294) "Ekspresi merupakan maksud, gagasan, perasaan, kemampuan ide yang diwujudkan dalam bentuk nyata". Gambar ekspresi dapat diartikan sebagai hasil coret-mencoret pada bidang dua dimensi dengan maksud menampilkan suatau wujud tertentu yang awalnya sudah dirasakan terlebih dahulu oleh manusia atau siseniman.

Tujuan menggambar bagi anak yaitu:

1.)Mengembangkan kebiasaan pada anak untuk mengekspresikan diri,

2.)Mengembangkan daya kreativitas,

3.)Mengembangkan kemampuan berbahasa, dan

4.)Mengembangkan citra diri anak dengan menggambar anak-anak juga dapat bersosialisasi dengan temannya.

\section{Gambar Anak-Anak pada Tahap Prabagan}

Menurut Loita (2017:10) "Gambar pada anak seakan muncul secara tiba-tiba tanpa direnungkan dan dipikirkan". Gambar anak-anak bersifat naif kerena merupakan curahan ekspresi yang spontan, polos, lugu dan apa adanya. Jadi di sini bukanlah kita akan mencepak anak-anak jadi seniman, akan tetapi mereka memperoleh kebebasan, keleluasaan dan kepuasan dalam berekspresi melalui kegiatan menggambar, walaupun akhirnya gambar yang dihasilkan memiliki
Gorga : Jurnal Seni Rupa

Volume 09 Nomor 01 Januari-Juni 2020

p-ISSN: 2301-5942 | e-ISSN: 2580-2380

warna yang berfariasi, aneh, unik, ataupun irrasional, itu wajar bagi anak-anak karena dalam mewujudkan suatu kreativitas emosi anak-anak juga mengambil peran.

\section{Alat dan Bahan Menggambar}

Sebelum memulai mengambar, terlebih dahulu kita tentukan objek yang akan kita gambar beserta media yang akan kita gunakan. Untuk menggambar kita dapat menggunakan peralatan dan bahan yang sederhana. Beberapa alat dan bahan yang kita perlukan untuk menggambar adalah sebagai berikut:

\section{1). Kertas}

Kertas adalah bahan (bidang gambar) yang paling ideal digunakan untuk menggambar. Pemilihan kertas yang baik untuk menggambar bentuk sangat membantu kemudahan waktu berkarya, karena sifat bahan akan menghasilkan efek tertentu. Jenis kertas yang baik adalah tidak licin, tidak mengkilat, tidak terlalu tipis, dan kertas yang permukaannya agak kasar atau bertekstur.

\section{2). Pensil}

Ada banyak jenis pensil yang dapat dipakai membuat gambar. Pensil terdiri dari beberapa spesifikasi yaitu pensil $\mathrm{H}, \mathrm{B}, 2 \mathrm{~B}, 3 \mathrm{~B}, 4 \mathrm{~B}, 4 \mathrm{~B}, 5 \mathrm{~B}, 6 \mathrm{~B}, 7 \mathrm{~B}, 8 \mathrm{~B}$, dan jenis EB. $B=$ black, berarti hitam. Semakin besar angka di depan kode $\mathrm{B}$, goresan pensil semakin lunak dan semakin hitam. Jenis $\mathrm{H}$ merupakan pensil dengan intensitas kehitaman paling rendah. Sementara jenis EB adalah pensil dengan intensitas kehitaman paling tinggi.

\section{3). Karet Penghapus}

Penghapus berguna untuk mengoreksi gambar. Bagian-bagian gambar yang sudah tidak diperlukan dapat dihapus, misalnya goresan dari bentuk pola dasar atau noda-noda yang tidak disengaja.

\section{4). Krayon}

Menurut Bagus (2016:02) “Ada dua jenis krayon yaitu wax dab oil pastel. Untuk mewarnai gambar gunakan krayon jenis oil pastel karena sifatnya yang lembut dan mudah bercampur dengan warna lain". Teknik mewarnai dengan krayon ada empat menurut menurut Bagus (2016:03) Pertama teknik blocking salah satu teknik dasar yaitu memblok bidang gambar dengan satu warna tertentu, kedua teknik gradasi adalah teknik mewarnai dengan cara member uratan warna yang seirama dan secara bertingkat, ketiga teknik kerik adalah teknik yang digunakan untuk member efek tertentu, dan keempat teknik graffito merupakan teknik dengan cara menimpa warna hitam diatas warna-warna dasar lalu dikerik. 


\section{Manusia}

Menurut Sunaryo (2015:12) "Tubuh manusia terdiri atas tubuh yang membentuk suatu keseluruhan yang rumit". Selajutnya menurut Panero (1979:01) "Tubuh manusia dirancang sedemikian rupa sehingga secara alamiah wajahnya, mulai dari dagu hingga kening bagian atas dan bagaian akar rambut yang terendah".

\section{Pengertian Bentuk}

Menurut Apriyanto (2004:05) "Bentuk adalah garisgaris yang bembentuk banguan dasar tiga dimensi". Selanjutnya Mesra (2014:08) "Bentuk adalah istilah yang gampang dikacaukan dengan raut, dalam bahasa inggris bentuk merupakan from, bentuk merupakan keseluruhan rupa sebuah rancangan walaupun raut merupakan unsure pengenal yang utama”.

\section{Pengertian Warna dalam Menggambar}

Menurut Bahari (2008:100) menuliskan pengertian warna dalam bukunya yang berjudul Kritik Seni Wacana, Apresiasi Dan Kreasi: "Warna adalah gelombang cahaya dengan frekuensi yang dapat memengaruhi penglihatan kita”. Menurut Dharsono (2007:40) "Dimensi kualitas warna terdiri dari yaitu: hue, value, dan intensity/chroma.Hue adalah istilah yang digunakan untuk menunjukkan nama dari suatu warna, seperti merah, biru, hijau, dan sebagainya. Munsel memilih 5 buah hue, yang merupakaan dasar yaitu: merah, kuning, hijau, biru, dan ungu. Value secara teoritis hanya membicarakan mengenai kegelapan dan kecerahan daripada warna. Menurut munsel ada 11 tingkatan value netral termasuk putih, hitam. Intensity/chroma diartikan sebagai gejala kekuatan/intensitas warna atau warna yang sangat mecolok."

\section{METODE PENELITIAN}

Metode penelitian yang digunakan yaitu metode peneltian kualitatif. Teknik pengumpulan data yang digunakan observasi dan dokumentasi. Instrumen peneltian yang digunkan yaitu buku catatan, Lembar Penilaian, dan Kamera. Teknik analisis data yang digunakan yaitu deskriptif kualitatif.

\section{HASIL DAN PEMBAHASAN}

1.Hasil

1). Karya 1

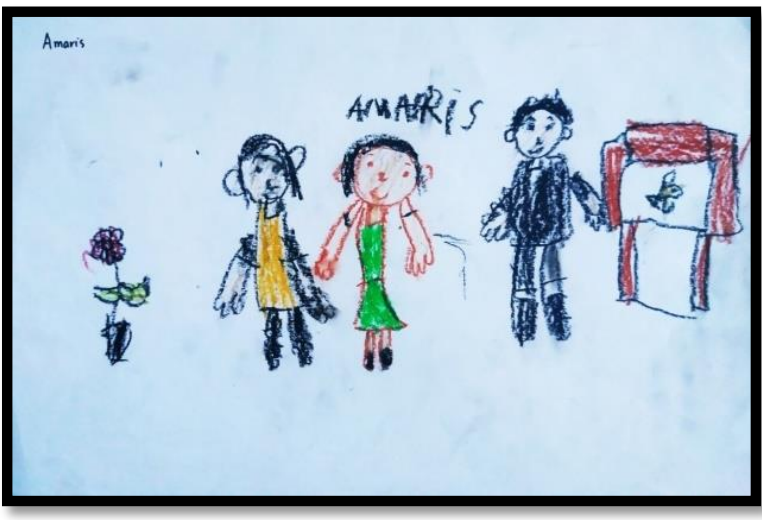

Gambar 1. Karya Amaris

(Sumber: Crosby Sitepu, 2019)

Karya gambar ekspresi objek manusia menggunakan krayon pada karya no 1 indikator karakter bentuk mendapat nilai Berkembang sesuai harapan (BSH) dengan jumlah rata-rata 75, untuk indikator warna mencapai nilai Berkembang sesuai harapan (BSH) dengan jumlah rata-rata 74 dan untuk indikator kerapian mencapai nilai Berkembang sesuai harapan (BSH) dengan jumlah rata-rata 73. Sehingga penerapan karakter bentuk, warna dan kerapian dikategorikan Berkembang sesuai harapan (BSH) dengan jumlah 222 dan dengan nilai rata- rata 74 .

Berdasarkan analisis peneliti, menampilkan suasana keluarga yang berkumpul dengan adanya penegasan karakter bentuk beserta pakaian anak perempuan, wanita dan pria dewasa. Warna pada karya no 1 telah berkembang dengan baik, karya gambar no 1 juga telah memberi warna yang sesuai dengan warna kulit manusia, tetapi satu gambar saja yang diberi warna sedangkan untuk dua gambar lainnya tidak diberi warna, karya no 1 juga memberi variasi warna pada bagian badan dan kaki sebagai ekspresi baju dan sepatu (pakaian). Kerapain pada karya gambar no 1 sudah mulai rapi, tetapi kekurangannya terdapat pada garis dan bercak warna diluar objek gambar.

Karya no 1 juga telah menampilakn tipe gambar anakanak pada tapah prabagan bahkan telah sampai pada tahap bagan sesuai dengan teori Lowenfeld (bentuk lingkaran sebagai kepala, persegi atau persegi panjang sebagai badan, leher, kaki, dan tangan menggunakan garis lurus). 


\section{2). Karya 2}

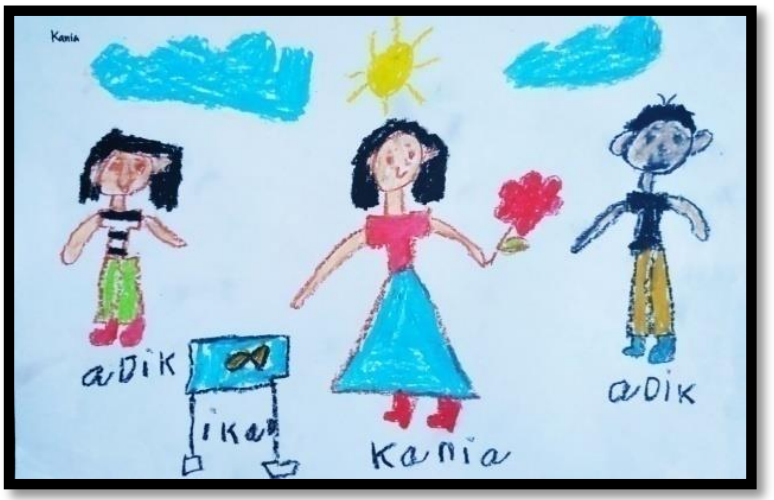

Gambar 2. Karya Kania

(Sumber: Crosby Sitepu, 2019)

Karya gambar ekspresi objek manusia menggunakan krayon pada karya no 2 indikator karakter bentuk mendapat nilai Berkembang sesuai harapan (BSH) dengan jumlah rata-rata 77 , untuk indikator warna mencapai nilai Berkembang sesuai harapan (BSH) dengan jumlah rata-rata 77 dan untuk indikator kerapian mencapai nilai Berkembang sesuai harapan (BSH) dengan jumlah rata-rata 76. Sehingga penerapan karakter bentuk, warna dan kerapian dikategorikan Berkembang sesuai harapan (BSH) dengan jumlah 231 dan dengan nilai rata- rata 77.

Berdasarkan analisis peneliti, menampilkan suasana keluarga pada siang hari yang berkumpul dengan adanya penegasan karakter bentuk beserta pakaian anak perempuan, wanita dan pria dewasa. Warna pada karya no 2 telah berkembang dengan baik, karya no 2 juga memberi variasi warna pada bagian badan dan kaki sebagai ekspresi pakaian. Kerapain pada karya gambar no 2 sudah sangat rapid an baik. Karya no 2 juga telah menampilakn tipe gambar anak-anak pada tapah bagan bahkan telah sesuai dengan teori Lowenfeld. Keunikan karya no 2 ada pada susuna alur cerita yang diungkapkan melalui tulisan berupa penjelasan dari tiap karakter.

\section{3). Karya 3}

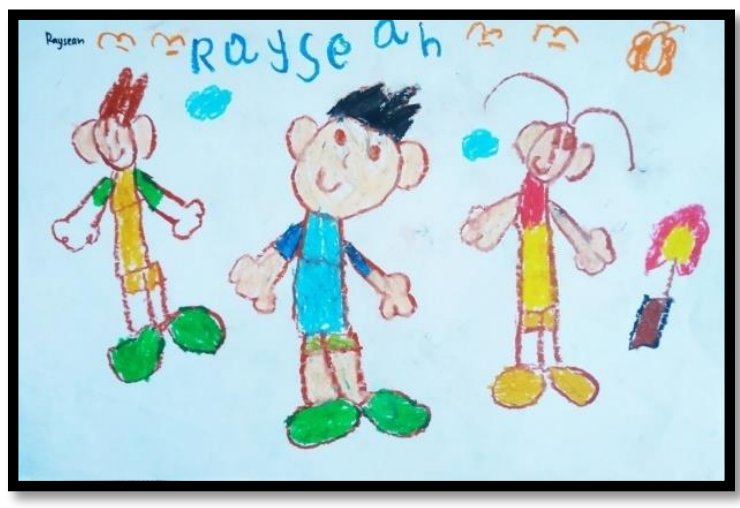

Gambar 3. Karya Raysean

(Sumber: Crosby Sitepu, 2019)

Karya gambar ekspresi objek manusia menggunakan krayon pada karya no 3 indikator karakter bentuk mendapat nilai Berkembang sesuai harapan (BSH) dengan jumlah rata-rata 78, untuk indikator warna mencapai nilai Berkembang sesuai harapan (BSH) dengan jumlah rata-rata 76 dan untuk indikator kerapian mencapai nilai Berkembang sesuai harapan (BSH) dengan jumlah rata-rata 75. Sehingga penerapan karakter bentuk, warna dan kerapian dikategorikan Berkembang sesuai harapan (BSH) dengan jumlah 229 dan dengan nilai rata- rata 76 .

Berdasarkan analisis peneliti, menampilkan suasana keluarga yang berkumpul dengan adanya penegasan karakter bentuk anak perempuan dan anak laki-laki. Warna pada karya no 3 telah berkembang dengan sangat baik, karya gambar no 3 juga telah memberi warna yang sesuai dengan warna kulit manusia, karya no 3 juga memberi variasi warna hijau, kuning, biru dan merah pada bagian badan dan kaki sebagai ekspresi baju dan sepatu (pakaian), dengan nilai 95. Kerapain pada karya gambar no 3 sudah terlihat rapi. Karya no 3 juga telah menampilakn tipe gambar anakanak pada tapah prabagan bahkan telah sampai pada tahap bagan sesuai dengan teori Lowenfeld. Karya gambar ini menampilakn suasana bermain ditaman pada siang hari.

\section{Pembahasan}

Berdasarkan analisis data dalam penelitian pada karya peserta didik kelas B 3 TK Methodist Berastagi maka yang diperoleh yaitu pada penilaian indikator karakter bentuk yang peraktekya sudah baik dan maksimal, peserta didik hanya perlu berlatih untuk mengekspresikan diri melalui kegiatan menggambar. Untuk indikator warna sudah sangat baik yang 
ditampilkan pada karya gambar ekspresi objek manusia menggunakan krayon peserta didik kelas Kelas B 3 TK Methodist Berastagi, para peserta didik dengan berani untuk mengekspresikan diri melalui warna yang digunakan dan pilih. Untuk indikator kerapian secara umun cukup baik dan mulai berkembang.

Kemapuan mengekspresikan diri melalui kegiatan menggambar para peserta didik sudah dapat dikatakan baik, karena selama kegiatan menggambar para peserta didik dapat fokus dan dengan percaya diri untuk melakukan kegiatan ini, walaupun terkadang masih ada yang bertanya kebingungan mengenai objek

Dengan adanya penelitain dan kegiatan menggambar ini telah diketahui ada beberapa peserta didik yang dapat mengikuti dengan baik tetapi kurang mampu untuk mengikuti pelajaran umum lainnya dan ada juga yang kesulitan mengikutinya tetapi bisa dalam mata pelajaran umum lainnya. Walaupun kegiatan seni rupa kurang diterapkan dalam kegiatan pembelajaran tetapi sebenarnya peserta didik TK B 3 Methodist Berastagi memiliki ketetariak lebih pada kegiatan menggambar, dapat dibuktikan sesuai hasil karya gambar ekspresi peserta didik TK B 3 Methodist Berastagi yang telah mencapai kategori berkembang sesuai harapan (baik).

\section{KESIMPULAN DAN SARAN}

\section{Kesimpulan}

Berdasarkan hasil penelitian dan pembahasan data, penulis memperoleh kesimpulan yang dapat diambil dari penelitian mengenai Tinjauan Gambar Ekspresi Objek Manusia Berdasarkan Teori Lowenfeld Menggunakan Krayon Oleh Anak TK B Methodist Berastagi sebagai berikut: Perkembangan karya gambar anak TK B Methodist Berastagi dengan teori Lowenfeld pada tahapan prabagan sangat baik dan ada beberapa anak yang telah mencapai tahap bagan disalah satu indikator. Hasil analisis menunjukkan bahwa kemampuan gambar ekspresi objek manusia menggunakan krayon oleh peserta didik TK B 3 Methodist Berastagi telah mencapai kategori berkembang dengan baik sesuai dengan hasil karya gambar ekspresi. Hasil analisis juga menunjukkan bahwa karakeristik gambar ekspresi peserta didik TK B 3 Methodist Berastagi berdasarkan teori Lowenfeld perkembangan seni rupa anak sudah sangat baik dan telah sesuai dengan tipe/tahap prabagan sejumlah 26 anak atau $100 \%$.

\section{Saran}

Berdasarkan kesimpulan dari hasil penelitian, maka peneliti memberikan beberapa saran sebagai berikut:
Hendaknya guru melakukan apresiasi berbagai jenis dan tipe gambar anakuntuk menambah wawasan dan pengetahuan tentang karakteristik gambar anak. Penilaian yang dilakukan terhadap gambar karya anak-anak semestinya disesuaikan dengan dunia anak. Pemberian stimulasi melalui metode bercerita, menunjukkan gambar-gambar, serta adanya pendekatan yang lebih intensif kepada setiap individu dapat meningkatkan imajinasi anak sehingga objek yang digambar oleh anak lebih bervariasi. Guru dapat mengembangkan gambar sesuai dengan karakteristik atau tipe gambar masing-masing anak, dengan memberikan cerita-cerita, gambar dan video sebagai media visual yang dapat mempengaruhi perasaan anak dan menambah daya imajinasi anak.

Orang tua senantiasa mendampingi dan memberikan dukungan kepada anak, dengan cara memenuhi apa yang dibutuhkan oleh anak dalam kegiatan menggambar dan kegiatan keseni rupaan lainnya, sehingga kebebasan anak dalam mengekpresikan imajinasi dalam duani seni rupa dapat diungkapkan secara maksimal. Harapan peneliti hendaknya penelitian ini dilanjutkan dan dikembangkan sehingga dapat memberikan manfaat yang berarti dalam dunia pendidikan khususnya dalam dunia pendidikan usia dini dan kesenirupaan anak usia dini.

\section{DAFTAR RUJUKAN}

Apriyanto, Very. (2004). Cara Mudah Menggambar Dengan Pensil. Jakarta : PT Kawan Pustaka

Bagus Sulistyo, Erlangga. (2016). Panduan Menggambar Dan Mewarnai Dengan Krayon. Jakarta : Cikal Aksara

Bahari, Nooryan. (2008). kritik seni : wacana, apresiasi dan kreasi. Yogyakarta : Pustaka Pelajar

Dharsono. (2007). Kritik Seni. Bandung : Rekayasa Sains

KBBI, (2014). Kamus Besar Bahasa Indonesia. Jakarta : Penerbit Gita

Loita, Aini. (2017). Karakteristik Pola Gambar Anak Usia Dini. Early Childhood. Jurnal

Pendidikan, 01 , 01-14

Lowenfeld, Viktor. (1958). Creative And Mental Growth. America : The Macmiilan Company

Mesra. (2014). Menggambar Bentuk 1. Medan : Unimed Press

Muhammad, As'adi. (2009). Panduan Praktis Menggambar Dan Mewarnai Untuk Anak Jogjakarta : Power Book (IHDINA)

Panero, Julius dan Zelnik, Martin. (1979). Dimensi Manusia Dan Ruang Interior. Jakarta : ERLANGGA 
Rohman, Irfan Abdul. (2010). Panduan Menggambar

Manusia Menggunakan Media Pensil 1.

Yogyakarta : Andi Offset

Susanto, Mikke. (2018). Diksi Rupa. Yogyakarta :

Dictiart Laboratory

Sunaryo, Aryo. (2015). Anatomi Plastis. Yogyakarta :

Ombak. 